\title{
CDC7 Kinase Inhibitor BMS-863233
}

National Cancer Institute

\section{Source}

National Cancer Institute. CDC7 Kinase Inhibitor BMS-863233. NCI Thesaurus. Code C82418.

An orally bioavailable cell division cycle 7 homolog (CDC7) kinase inhibitor with potential antineoplastic activity. CDC7 kinase inhibitor BMS-863233 binds to and inhibits the activity of CDC7, which may result in the inhibition of DNA replication and mitosis, the induction of tumor cell apoptosis, and the inhibition of tumor cell proliferation in CDC7overexpressing tumor cells. CDC7, a serine-threonine kinase overexpressed in a variety of tumor cell types, plays an essential role in the initiation of DNA replication by activating origins of replication. 